\title{
Sponsors
}

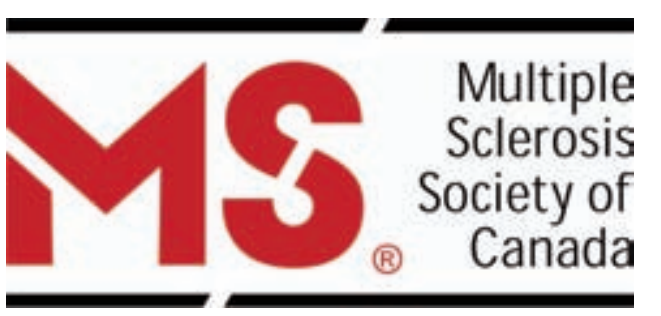

\section{Alberta Health Services}
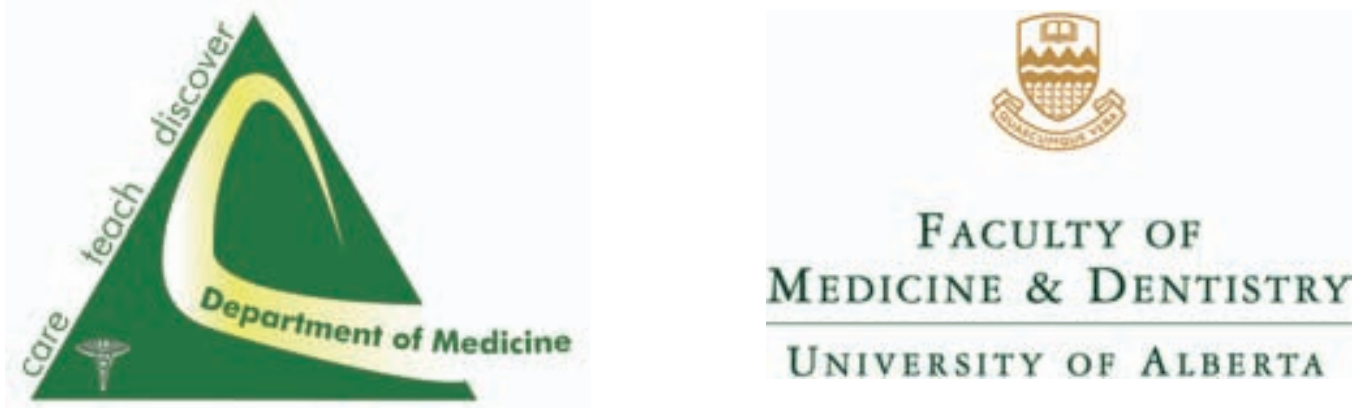